\title{
Dividend taxation and intertemporal tax arbitrage ${ }^{\hbar}$
}

\author{
Anton Korinek ${ }^{\mathrm{a}, *, 1}$, Joseph E. Stiglitz ${ }^{\mathrm{b}, 2}$ \\ a University of Maryland, USA \\ ${ }^{\mathrm{b}}$ Columbia University, USA
}

\section{A R T I C L E I N F O}

\section{Article history:}

Received 4 September 2006

Received in revised form 31 July 2008

Accepted 8 August 2008

Available online 20 August 2008

\section{JEL classification:}

G35

G38

H32

Keywords:

Dividend taxation

Capital constraints

Aggregate investment

Political economy of taxation

\begin{abstract}
A B S T R A C T
We analyze the effects of changes in dividend tax policy using a life-cycle model of the firm, in which new firms first access equity markets, then grow internally, and finally pay dividends when they have reached steady state. We find that unanticipated permanent changes in tax rates have only small effects on aggregate investment, since macroeconomic dynamics are dominated by mature firms for which dividend taxation is not distortionary. Anticipated or temporary dividend tax changes, on the other hand, create incentives for firms to engage in inter-temporal tax arbitrage so as to reduce investors' tax burden. For example, a temporary tax cut - the type most likely to be enacted by policymakers - induces firms to accelerate dividend payments while tax rates are low, which reduces their cash holdings and makes them capital-constrained when large investment opportunities arise. This can significantly lower aggregate investment for periods after the tax cut.
\end{abstract} (c) 2008 Elsevier B.V. All rights reserved.

\section{Introduction}

The economic effects of dividend taxation have been at the center of a fierce academic debate for decades. Proponents of the 'traditional view' of dividend taxation (as discussed e.g. in Poterba and Summers, 1985) stress that it raises the cost of equity finance. Hence, they argue, it distorts firms' investment decisions, and higher dividend taxes decrease the long-run capital intensity of an economy. The 'new' or 'tax capitalization view,' by contrast, which was developed in King (1977) and Auerbach (1979), extending an earlier argument of Stiglitz (1973), ${ }^{3}$ assumes that firms use retained earnings as the marginal source of finance; the level of dividend taxation is thus irrelevant for their investment decisions.

In this paper, we explicitly take this controversy into account by modeling the life cycle of firms. Following the discussion in Stiglitz $(1973,1976)$ and Sinn (1991), firms in our model go through three stages: When they are started, their marginal source of

\footnotetext{
The authors would like to express their thanks for helpful comments to Raj Chetty, Allan Drazen, Jianjun Miao, Jim Mirrlees, Jim Poterba, Joel Slemrod and Michael Woodford as well as to two anonymous referees and to participants at a conference at Cambridge University in honor of Mirrlees' 70th birthday, a workshop at the University of Manchester, an NBER Public Economics Program Meeting, an NBER Universities Research Conference, the 2008 AEA Meetings, and a seminar at Columbia University.

* Corresponding author. 4118F Tydings Hall, University of Maryland, College Park, MD 20742, USA. Tel.: +1 3014054536.

URL: http://www.korinek.com/ (A. Korinek).

1 Korinek acknowledges financial support from the Austrian Academy of Sciences.

2 Stiglitz acknowledges financial support from the Ford, MacArthur, and Mott foundations.

${ }^{3}$ Stiglitz (1973) demonstrated that it was more tax-efficient to distribute funds to shareholders by buying back shares than by paying dividends, with effective tax rates that are markedly lower than the dividend tax rate. The fact that so much money is nonetheless distributed through dividends has subsequently come to be called the 'dividend puzzle' (see Black, 1976).

We do not address this puzzle here - we simply assume that all payouts from the firm are subject to the dividend tax, as if there were no stock repurchases. The results of our analysis are valid so long as firms engage - at the margin - in intertemporal arbitrage. Even if they irrationally distribute funds in the form of dividends, they can be and should be sensitive to the fact that by distributing dividends in low-tax periods they increase shareholder value.
} 
finance is equity markets. As predicted by the traditional view, dividend taxation is distortionary for such firms. In the second stage, firms grow internally by retaining all their earnings until they reach their optimal size. In the final stage, or steady state, they pay out their earnings in the form of dividends.

In Sinn (1991), the only way for firms to carry resources from one period to the next is by first investing into physical capital, which exhibits strictly decreasing returns, and then liquidating the investment the following period. This severely limits firms' ability to engage in intertemporal tax arbitrage. By contrast, our paper emphasizes that firms routinely hold cash or cash equivalents to carry resources into the future, without being subject to the decreasing returns exhibited by physical capital. This enables them to arbitrage between different tax regimes, with important efficiency implications.

In our model, firms' steady state cash holdings are determined as a tradeoff between two considerations, imperfect access to capital markets and agency costs of holding cash: We capture the first consideration by assuming that investment opportunities arrive randomly, yet that firms cannot raise new funds in capital markets instantaneously; they need to carry cash on their balance sheets in order to take advantage of investment opportunities. The second consideration is that agency problems induce investors to discount future dividend flows from firms at a higher rate than the returns of cash on hand. This is consistent with a wide variety of models of agency concerns; a specific example based on managerial myopia is given in the Appendix A. A firm's equilibrium level of cash balances trades off the expected benefit of holding cash for investment against the cost of holding cash balances; this implies that firms are capital constrained in equilibrium.

As postulated by the traditional view of dividend taxation, we show that dividend taxation is distortionary for young firms that issue new equity. ${ }^{4}$ Let us capture the logic of this in the simplest possible model, where $i$ represents the amount invested, $r$ is investors' required return and $\tau$ the dividend tax rate. We can then define a firm's optimum amount of investment as the point where the investors' opportunity cost of funds equals the marginal return of funds net of dividend taxation.

$$
1+r=(1-\tau) f^{\prime}(i) .
$$

The higher the tax rate, the lower the return of firm investment to the shareholder; therefore the higher the required marginal gross product of capital and the lower investment.

On the other hand, an internally growing or mature firm that finances investment out of its cash reserves has to reduce its dividend in the current period, which entails a marginal cost to shareholders of $(1-\tau)(1+r)$, and can distribute the return of the investment net of taxes next period. The resulting equilibrium condition is

$$
(1-\tau)(1+r)=(1-\tau) f^{\prime}(i) .
$$

The tax rate cancels out of firms' optimality condition; a constant level of dividend taxation therefore does not affect the investment decisions of internally growing or mature firms that do not access equity markets. Since these two categories of firms dominate aggregate investment, the effect of the level of dividend taxation on investment is low at a macroeconomic level. By the same logic, the impact of unanticipated permanent tax changes on macroeconomic variables is generally small, since they affect only young firms that raise new equity.

By contrast, anticipated tax changes have macroeconomic effects that can be an order of magnitude higher: they allow mature firms to engage in inter-temporal tax arbitrage by shifting dividend payments from high-tax periods to low-tax periods. This involves significant deviations from firms' optimal steady state cash holdings, and since firms are capital constrained, changes in their cash holdings can significantly distort aggregate investment and output.

An anticipated dividend tax cut allows firms to reduce investors' tax bill by postponing dividend payments to the period in which the tax cut takes place. This implies that firms carry larger cash balances in the meantime, which allows them to make larger investments when an investment opportunity arrives.

By the same token, an anticipated dividend tax increase creates an incentive for firms to accelerate their dividend payments, i.e. to take advantage of the low tax rate while it lasts by paying out a special dividend before the increase takes place. This leads to lower cash balances and in turn lower investment in the following periods. Using the simplified notation from above, an increase in the tax rate from $\tau_{L}$ to $\tau_{H}$ implies that paying out dividends becomes comparatively cheaper than investing and distributing the payoff under a higher tax rate. The equilibrium level of investment $i$ is then given by

$$
\left(1-\tau_{L}\right)(1+r)=\left(1-\tau_{H}\right) f^{\prime}(i) .
$$

When dividend taxes are expected to change, the tax terms no longer cancel; instead we can show that the required return for an investment is higher and the firm will invest less: ${ }^{5}$

$$
f^{\prime}(i)=(1+r) \frac{1-\tau_{L}}{1-\tau_{H}}>1+r .
$$

\footnotetext{
${ }^{4}$ Implicitly, much of the literature on corporate taxation and investment has assumed the existence of capital constraints; for in the absence of such constraints, firms could always finance their investment at the margin by debt; with interest payments tax deductible, there would be no marginal distortion. See Stiglitz $(1973,1976)$. As we note later, our analysis is consistent with partial debt financing.

5 Note that for simplicity, this simple two-period example of a tax increase abstracts from the difference between a firm's cash holdings and physical capital as much of the existing literature does. For tax cuts, a thorough analysis necessitates that cash holdings are explicitly taken into account, as we do in the full model in Section 2.
} 
A temporary dividend tax change can be viewed as an unanticipated change followed by a second anticipated change in the opposite direction. As we argued, the arbitrage effects of the anticipated reversal are likely to far outweigh any efficiency effects of the first unanticipated change. A temporary dividend tax cut, for example, is thus likely to have an overall negative impact on aggregate investment and output. Similarly, uncertainty about an impending dividend tax increase can lead firms to reduce their cash holdings, with the corresponding negative macroeconomic effects.

We also discuss the political economy implications of dividend taxation in a contestable democracy with two parties, conservatives and social democrats, that have different preferences regarding dividend taxation and adjust the tax rate accordingly when they come to power. Paradoxically, aggregate investment is higher under social democratic rule, since firms expect a tax cut when that party loses power and hold higher cash reserves in anticipation. Under a conservative regime, the opposite conclusions hold.

Aside from providing new insights into the consequences of the temporary dividend tax cuts that were introduced in the United States in 2003 and extended in 2006, this paper also makes a point about the political economy of government policies of more general import: in contestable democracies, the effects of policies have to be analyzed in the context of an environment in which economic agents expect (stochastically) a change in decision makers and in government policies. It is wrong simply to assume, as much of the political economy literature has done heretofore, that government policies can be altered permanently. Political turnover and the resulting policy instability affect the behavior of economic agents, and rational decision makers have to take this into account in formulating their policies.

\subsection{US dividend tax policy in the current decade}

In analyzing the implications of dividend tax policy on firm behavior and the macro-economy, it is important to take account of both implemented tax changes and expectations thereof. In the United States dividends used to be taxed at the personal income tax rate of up to $38.6 \%$ in the late 1990s. In his campaign for the 2000 presidential election, George W. Bush ran on a broad platform of lowering taxes so as to reduce the high predicted fiscal surplus over the coming decade. As a result, rational, forward-looking firms must have assigned a positive probability to a cut in dividend taxes. Indeed, in May 2003, the Jobs and Growth Tax Relief Reconciliation Act (JGTRRA) reduced the maximum personal income tax rate on corporate dividends to $15 \%$, with an expiration date of 2008.

While many conservatives argued that this tax cut should be made permanent, an increasing number of critics called for an early repeal, especially after the anticipated fiscal surplus quickly disappeared and the country was confronted with large fiscal deficits. The critics included Senator Kerry who ran against President Bush in the 2004 presidential elections. During the election campaigns of 2004, firms must thus have assigned a positive probability to all three events - the scheduled expiration of the tax cuts in 2008 as well as an extension or an early repeal. This latter possibility made it optimal to pay out large dividends in 2004, as exemplified by a $\$ 32$ bn special dividend by Microsoft.

When Bush won re-election in 2004, expectations adjusted again: an early repeal of the tax cut no longer seemed likely. Instead, a special budget reconciliation bill in May 2006 extended the dividend tax cuts to the end of 2010. At least partly as a result of these policies, the fraction of dividends in national income jumped from $4.4 \%$ in 2003 to $6.5 \%$ in 2007 - a level not seen since 1930 . $^{6}$

In 2008, the Republican presidential candidate Senator McCain called for making the 2003 dividend tax cut permanent, where "permanent" has to be understood in the context of a political economy in which future governments are likely to change course again, as we discuss in Section 5. By contrast, the Democratic candidate Senator Obama advocated a repeal of the cut. Again, firms were faced with the fundamental uncertainty that is inherent in every public policy and that is the topic of our paper.

\subsection{The academic debate on dividend taxation}

A number of researchers have empirically investigated the impact of the 2003 dividend tax cut on firms' payout behavior. There is evidence that the tax cut has led to a significant increase in both special and regular dividend payouts (see e.g. Blouin et al., 2004; Chetty and Saez, 2005), consistent with our view that the policy change induced firms to engage in intertemporal tax arbitrage. ${ }^{7}$

Chetty and Saez (2005) and Brown et al. (2007) also document that firm responses to the dividend tax cut differed depending on the specific incentives faced by executives and shareholders. For example, firms with large inside ownership or a large and influential outside shareholder that is subject to dividend taxation were more likely to raise dividends in response to the tax cut. While our model describes the behavior of representative firms, our basic insights would be unaffected if we account for this form of firm heterogeneity.

Amromin et al. (2007) and Auerbach and Hassett (2006, 2007) find that the 2003 tax cut also had a significantly positive effect on the share prices of high dividend-paying stocks, which suggests that their marginal cost of equity finance was reduced. In

\footnotetext{
${ }^{6}$ Data from the webpage of the Bureau of Economic Analysis, U.S. Department of Commerce, http://www.bea.gov, Table 1.12.

7 It is also likely that part of the observed increase in dividends was due to cyclical and secular increases in firm profits and due to substitution between share repurchases and dividends, as suggested e.g. by Brown et al. (2007). However, according to Chetty and Saez (2006), the existing data is not yet sufficient to provide a definite answer to this question. In our analysis, the distinction between regular and special dividends is immaterial: just as tax policies are never "permanent," so are firms' payout policies: for signaling or intertemporal smoothing reasons firms might prefer to gradually lower their cash balances for the duration of the low dividend tax rate by raising regular dividends. Also, they might rationally anticipate that a future tax increase could allow them to cut regular dividends with only small adverse signaling effects.
} 
popular opinion, such findings have often been interpreted as an indication that the dividend tax cut had a positive effect on aggregate investment.

Our paper argues that this view is incomplete, if not incorrect. Indeed, there may be little relationship between share prices and investment. We discussed earlier (and show more rigorously below) that temporary dividend tax reductions can be associated with an increase in share prices but a lowering of investment.

Some of the proponents of the dividend tax cut have also argued that certain firms with large cash holdings engage in socially wasteful investments so that their net marginal return to investment is actually negative. ${ }^{8}$ If such firms are encouraged to pay out dividends, economic efficiency could be increased for two potential reasons: first, cash-abundant firms would no longer engage in as much wasteful investment; secondly, their cash distributions could get reshuffled to cash-constrained firms with a higher marginal product of capital.

The first reason, that there was over-investment and that it would have been a good thing for investment to be reduced in some firms, runs at least counter to the professed argument for the 2003 temporary dividend tax cut, which was introduced to stimulate the economy in the belief that aggregate investment was too low at the time. There may have been some firms, where agency problems were so severe that managers made inefficient investments at the margin ${ }^{9}$ and for which a temporary reduction in dividend taxes that reduced investment may have been welfare increasing. However, at least the average product of capital inside firms seems to be significantly larger than the risk-free rate. ${ }^{10}$ This casts doubt on the claim that a large number of firms exhibit a negative marginal product of investment. If shareholders believe that the marginal returns to keeping funds inside the firm are less than their (outside) opportunity costs, they can and presumably would demand larger cash distributions. ${ }^{11}$

Secondly, for the tax cuts to raise the efficiency of the capital allocation in the economy, payouts must be reinvested in new investment projects. However, it is generally much easier for government policies to get money out of the corporate sector than to put it back in. An important factor that inhibits this 'recycling of capital' is asymmetric information (see e.g. Stiglitz and Weiss, 1981; Greenwald et al., 1984). Another factor can be international capital flows that break the link between domestic saving and investment (see e.g. Slemrod, 1988) and that have become a major force in driving US interest rates in recent years.

Chetty and Saez (2007) argue that the observed increases in dividend payments after the 2003 tax cut stem from a shift from wasteful towards productive investments, implying large welfare gains from the dividend tax cuts. As our paper shows, there are other explanations for increases in dividend payments - with opposite welfare impacts, especially in the context of temporary tax changes.

There are several other dimensions of heterogeneity that may determine a firm's responses to dividend taxes. If markets are rational, a temporary dividend tax cut will affect only firms that are expected to pay dividends while the low tax rate is in effect. However, among the more dynamic sectors of the economy are the 'new economy' sectors, where any payouts are largely in forms that are subjected to capital gains taxation. ${ }^{12}$ Capital market imperfections (such as the absence of good risk markets, etc.) mean that there may be underinvestment in this part of the economy, relative to the 'old' and mature dividend paying firms. This is true without agency problems, but even more so with agency problems. Lowering dividend taxes advantages the old economy, as opposed to firms in the new economy, and thus may exacerbate the inefficiency of capital allocation. ${ }^{13}$

Those firms that pay out dividends and whose share prices should therefore benefit from temporary dividend tax cuts are mostly mature firms that do not issue equity and have little to gain from a lower cost of equity. Share prices and the cost of equity for new firms that do issue equity should be hardly affected by a temporary tax cut, since they are unlikely to pay dividends while the low tax rate is in effect. ${ }^{14}$

Our analysis does not take into account the budget deficits/revenue shortfalls created by the dividend tax cut. In the absence of lump-sum taxation, any replacement taxes that make up for the lost revenue will introduce further distortions. If taxes are not raised, a higher stock of public debt may increase interest rates at the margin and thereby discourage investment. ${ }^{15}$

\footnotetext{
${ }^{8}$ Jensen (1986), for example, emphasized the potential agency costs of free cash flow. Gordon and Dietz (2009) and Chetty and Saez (2007) build these considerations into their models of dividend taxation.

9 This assumes that take-over mechanisms do not work well - for reasons suggested by e.g. Stiglitz (1972), Grossman and Hart (1980) and Edlin and Stiglitz (1995).

10 This is e.g. one of the findings of the literature on the equity premium puzzle, which asserts that a large part of the equity premium cannot be satisfactorily explained by risk aversion (Mehra and Prescott, 1985; Kocherlakota, 1996).

11 Indeed, a standard response to "excess cash holdings" by firms and the associated agency problems is what Hall (1988) termed the "backs-to-the-wall" approach of corporate finance: shareholders demand large pay-outs from managers, leaving firms equity-constrained, as we model in this paper. This not only removes the scope for excess investment, but the increased probability of bankruptcy to which it gives rise enhances managerial incentives (see Greenwald and Stiglitz, 2003). Theories of excess corporate liquidity presume not only that shareholders cannot control managerial misbehavior, but also that they cannot effectively control dividend distributions to mitigate such behavior.

12 These 'smart' sectors are not only smart in innovation; they have also figured out the dividend puzzle.

13 This provides support for one of the political criticisms of the temporary dividend tax cuts, that they benefited the interests of old and stagnant industries rather than those of young and dynamic industries. It is perhaps no accident that the Secretaries of Treasury in office at the time of both tax cuts had been CEO's of "old economy" firms; and that the sway of "new economy" firms was markedly lower in the Bush Administration than in the Clinton Administration.

14 Empirically, there is a controversy regarding the impact of the tax cut on the share prices of non-dividend paying firms: Auerbach and Hassett (2006, 2007) find that the share prices of firms that are likely to issue new equity increased significantly as a result of the tax cut; Amromin et al. (2007) argue that the same effect can be found for REITs and European stocks that are not affected by US dividend tax policy and should therefore be attributed to other market factors. As we show in this paper, some of the ambiguity might be due to the fact that in 2003 , investors assigned a positive probability to a more permanent extension of the temporary tax cuts.

15 In the theoretical literature, Gourio and Miao (2007) perform a similar analysis, though mostly for the case of mature firms. As in Sinn (1991), firms in their model engage in intertemporal tax arbitrage by adjusting the physical capital stock, which is subject to both decreasing returns to scale and adjustment costs. By contrast, this paper explicitly allows firms to accumulate cash holdings, which better accounts for the behavior of firms that experience tax arbitrage opportunities (a clear example being Microsoft). Furthermore, we aggregate over firms of all three stages of development so as to analyze the behavior of macroeconomic variables.
} 
In Section 2 we develop our basic life-cycle model of capital constrained firms with random investment opportunities that are subject to dividend taxation. Section 3 investigates the effects of unanticipated and anticipated dividend tax changes on firm behavior. Section 4 analyzes how dividend tax policy affects macroeconomic variables such as aggregate investment. Section 5 briefly discusses a simple model of the political economy of dividend taxation. Section 6 concludes.

\section{Model}

Our model incorporates two key economic considerations: First, holding cash is costly for firms. Cash holdings within firms are discounted at a higher rate than cash holdings outside, because of agency concerns (including managerial myopia) and because of imperfections in risk markets, which may result in households being even more credit rationed than firms. Analytically, we assume that the discount factor $\beta$ on firms' future distributions is lower than the risk-free discount factor $\frac{1}{1+r}$, where $r$ is the risk-free interest rate. $^{16}$

Secondly, because of capital market imperfections, firms cannot instantaneously raise new capital for investment purposes they have to rely on their working capital. In our model, these constraints become particularly important because we assume that investment opportunities arrive at random. ${ }^{17}$ If firms do not have cash on hand, these investment opportunities have to be forgone. As a result, firms have an incentive to hold working capital - to give them the resources to take advantage of new opportunities as they arrive - even though the rate of interest that they earn on cash is lower than the discount rate they face.

Our model allows us to analyze precisely these intertemporal trade-offs. Suppose that the amount of cash a firm has on hand at the beginning of period $t$ is $M_{t}$. The firm decides how much new equity $N_{t}$ to issue and how much to pay in dividends $D_{t}$. This results in total cash holdings of $M_{t}+N_{t}-D_{t}$ on the firm's balance sheet.

Note that for the firm to raise $N_{t}$ in new equity, investor have to pay $(1+\kappa) N_{t}$, where the premium $\kappa \geq 0$ captures transactions costs, which can include e.g. underwriting fees (see Chen and Ritter, 2000) and underpricing because of agency problems (see e.g. Asquith and Mullins, 1986).

After completing their financial transactions, the firm can engage in real investment decisions. To capture the random arrival of investment opportunities, we assume that a Bernoulli variable $\tilde{\lambda}_{t}$ indicates every period whether a firm has an investment project. $\tilde{\lambda}_{t}$ takes on the value of 1 with probability $p$, which indicates that the firm can invest, and 0 with probability $(1-p)$. If a firm has a project, then investing $I_{t}$ dollars yields a pay-off of $F\left(I_{t}\right)$ at the end of period $t$, with $F(\cdot)$ being a neoclassical production function, e.g. of the form $F\left(I_{t}\right)=A I_{t}^{\alpha}$. For notational convenience we define a corresponding net production function, or net profits $G\left(I_{t}\right)=F\left(I_{t}\right)-(1+r) I_{t}$. Reflecting imperfect capital markets, investment is limited by the amount of cash that a firm keeps on its balance sheet

$$
I_{t} \leq M_{t}+N_{t}-D_{t} .
$$

If a firm does not have an investment project, it keeps its cash holdings in a bank account and earns interest at rate $r$ on it. ${ }^{18}$ And thus the basic law of motion for cash holdings is

$$
\tilde{M}_{\mathrm{t}+1}=(1+r)\left[M_{t}+N_{t}-D_{t}\right]+\tilde{\lambda}_{\mathrm{t}} G\left(I_{t}\right) .
$$

Managers maximize the stock market value of the representative firm, i.e. the stream of after-tax dividends minus the cost of equity issues, discounted by the factor $\beta$ that reflects the agency problem:

$$
V\left(M_{0} ; \tau\right)=\max _{\left\{D_{t}, I_{t}, N_{t}, M_{t+1}\right\}_{t=0}^{\infty}} E\left\{\sum_{t=0}^{\infty} \beta^{t}\left[(1-\tau) D_{t}-(1+\kappa) N_{t}\right]\right\}
$$

$$
\begin{aligned}
& \text { s.t. constraints (1), (2), } D_{t} \geq 0, N_{t} \geq 0 \\
& \text { with } M_{0}>0 \text { given. }
\end{aligned}
$$

The constraints on $D_{t}$ and $N_{t}$ in Eq. (4) capture that both dividends and new equity issuance have to be non-negative. ${ }^{19}$ Substituting the law of motion (2) we can re-write the maximization problem in recursive form:

$$
V\left(M_{t} ; \tau\right)=\max _{D_{t}, I_{t}, N_{t}}(1-\tau) D_{t}-(1+\kappa) N_{t}+\beta E V\left((1+r)\left[M_{t}+N_{t}-D_{t}\right]+\tilde{\lambda}_{t} G\left(I_{t}\right) ; \tau\right) \quad \text { s.t. }(4)
$$

\footnotetext{
${ }^{16}$ For simplicity, there is no aggregate market risk in our model; therefore the risk-free rate would be the appropriate discount rate in the absence of the discussed market imperfection. See appendix A for a motivation of the discount factor $\beta<\frac{1}{1+r}$ from micro fundamentals based on a model of managerial myopia.

17 Theories of asymmetric information, such as Stiglitz and Weiss (1981) and Myers and Majluf (1984), have explained why firms may face credit and equity constraints. Our analysis does not depend on the particular explanation for the constraints, only on the fact that such constraints exist.

${ }^{18}$ In our model, we assume that the rate of interest is fixed, e.g. as would be the case in a small open economy. As discussed in Sinn (1991), qualitative results would be similar if the interest rate adjusted as firms paid out higher dividends.

19 In the absence of any distortions, dividend payments would simply be the mirror image of new equity issuance. However, dividends are reduced by taxation, while the cost of new equity is augmented by issuance costs. The constraints ensure that firms cannot circumvent dividend taxes by redeeming equity or circumvent issuance costs through negative dividend payments.
} 


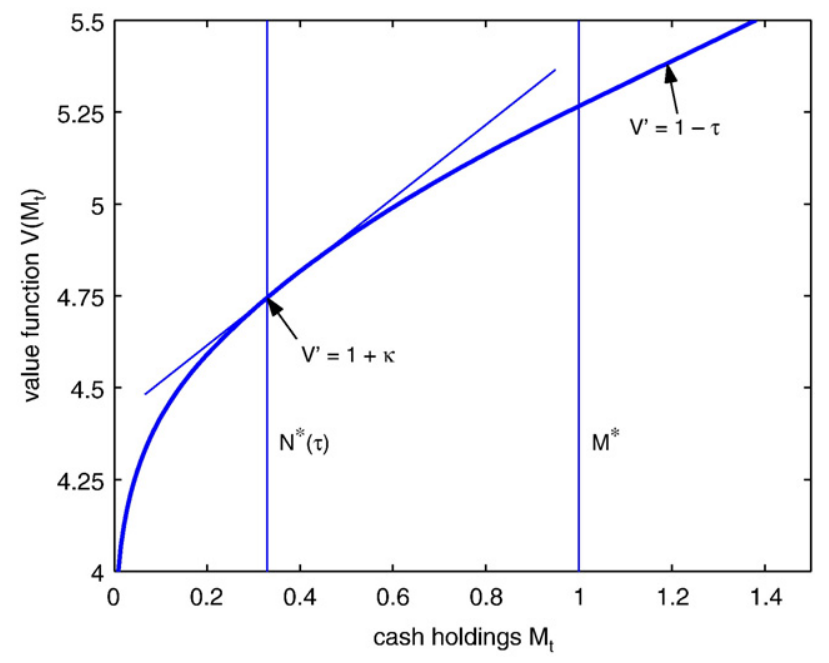

Fig. 1. Firm Value Function: Firms with $M_{t}<N^{*}(\tau)$ issue new equity; firms with $N^{*}(\tau) \leq M_{t}<M^{*}$ reinvest all earnings and grow internally; firms with $M_{t} \geq M^{*}$ are mature and pay dividends. (Parameter values: $\alpha=1 / 2, \beta=0.93, r=0.01, p=1 / 2, \tau=38.6 \%$, $A$ calibrated so that $M^{*}=1$.)

Given an initial cash balance of $M_{t}$, the firm chooses every period how much new equity $N_{t}$ to issue and how much to pay out in dividends $D_{t}$ (which simultaneously determines the amount of cash left on its balance sheet), as well as how much to invest in case an investment opportunity arises.

It can be shown that the steady state value $M^{*}$ for a firm's cash holdings is defined by the equation ${ }^{20}$

$$
\beta\left[p F^{\prime}\left(M^{*}\right)+(1-p)(1+r)\right]=1 .
$$

The term in square brackets represents the expected gross return of cash; it consists of the return if an investment opportunity arises (with probability $p$ ) and the return if cash is kept in T-bills (with probability $1-p$ ). The optimum level of cash balances $M^{*}$ is reached when the expected return discounted by $\beta$ is unity. Condition (6) is independent of the level of dividend taxes - the behavior of mature firms is unaffected by dividend taxation. Pre-multiplying both sides of the equation by $(1-\tau)$, the left side of Eq. (6) can be interpreted as the marginal payoff to investors of keeping one dollar of cash in the firm and the right hand side as the marginal payoff of paying out one dollar in dividends, i.e. $1-\tau$. For firms in steady state, the two sides have to equal.

As shown in Fig. 1, the firm's value function is strictly concave with a slope $V^{\prime}\left(M_{t}\right)>1-\tau$ for $M_{t}<M^{*}$. It is linear with slope $V^{\prime}\left(M_{t}\right)=1-\tau$ for mature firms with $M_{t} \geq M^{*}$. Following the arguments of Stiglitz $(1973,1976)$ and Sinn $(1991)$, we show that the behavior of firms can be analyzed by looking at three distinct stages, at new firms, growing firms and mature firms, depending on the level of cash holdings inside a given firm.

\subsection{New firms}

New firms or existing firms with $M_{0}<N^{*}(\tau)$ raise equity up to the threshold $N^{*}(\tau)$, i.e. they set $N_{t}=N^{*}(\tau)-M_{t}$. The threshold $N^{*}(\tau)$ is determined as the point where the slope of the firm's value function as defined by Eq. (5) equals the cost of raising equity, as indicated by a tangent of slope $1+\kappa$ in Fig. $1:^{21}$

$$
V^{\prime}\left(N^{*}(\tau) ; \tau\right)=1+\kappa
$$

New firms do not pay dividends $D_{t}=0$ since the marginal value of their cash holdings, $V^{\prime}=1+\kappa$ after raising equity, is higher than the marginal value of dividends, $1-\tau$. When an investment opportunity arises, they invest their entire cashholdings $I_{t}=M_{t}+N_{t}$.

\subsection{Growing firms}

For $M_{t} \in\left[N^{*}(\tau), M^{*}\right)$ the firm's marginal value of funds is too low to raise new equity, but too high to pay out dividends, i.e. $1+\kappa \leq V^{\prime}\left(M_{t}\right)<1-\tau$. In this region, a firm grows internally by investing and retaining its earnings until it reaches the steady state with $M_{t}=M^{*}$. Such a firm neither raises equity nor issues dividends, i.e. $N_{t}=D_{t}=0$, and invests its entire cash holdings when an investment opportunity arises, i.e. $I_{t}=M_{t}$.

\footnotetext{
20 A detailed analytical derivation of the results in this section is available from the authors upon request.

21 In our analysis, firms only issue equity once. In practice, young firms often issue equity in several tranches because of asymmetries of information: insiders may know (or believe) that information will become available that will reveal that the true value of the company is higher than currently believed.
} 

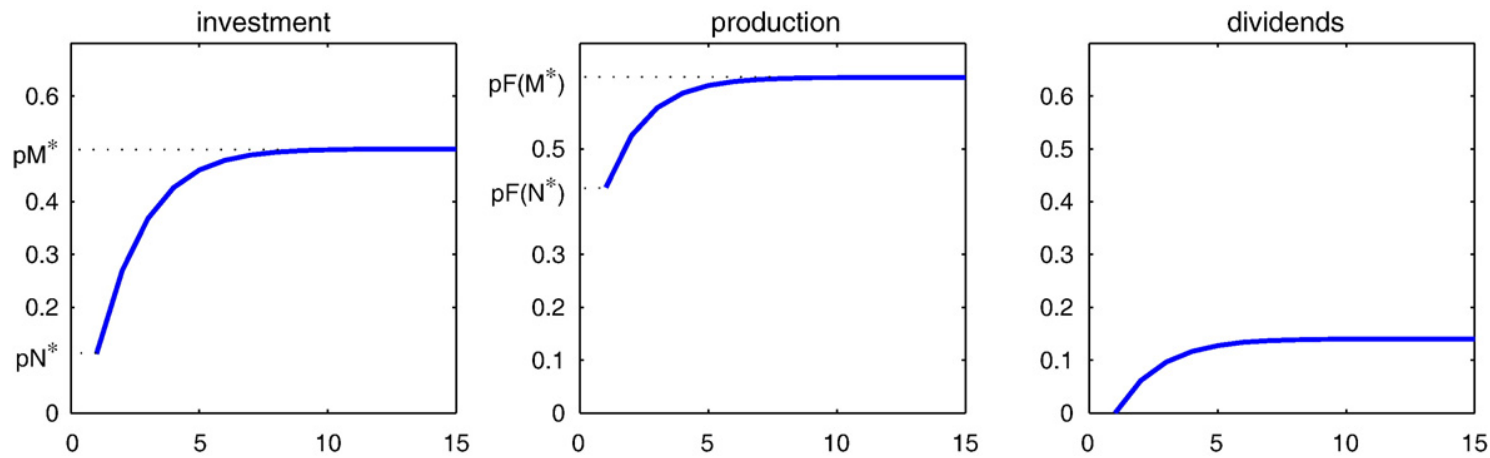

Fig. 2. Average Evolution of Firm: The figure shows how investment, production, and dividend payments for a new firm evolve in expectation over the first 15 periods. In the first period, the firm raises $N^{*}(\tau)$, it invests on average $p N^{*}$ and produces $p F\left(N^{*}\right)$. In period 15 , expected investment and production are almost indistinguishable from the steady state values $p M^{*}$ and $p F\left(M^{*}\right)$.

\subsection{Mature firms}

A firm with $M_{t} \geq M^{*}$ is in its steady state. Every period, it pays out its cash holdings in excess of the optimal holdings $M^{*}$ in the form of dividends $D_{t}=M_{t}-M^{*}$. If an investment opportunity arises, then the firm invests $I_{t}=M^{*}$ and earns $F\left(M^{*}\right)$. Next period the firm distributes all but the amount of cash required for new investments, i.e. it pays a dividend $D_{t+1}=F\left(M^{*}\right)-M^{*}$. Otherwise, if no investment opportunity arises, it earns interest of $r M^{*}$, which it pays out at the beginning of the next period. ${ }^{22}$ Once the firm has reached the threshold $M^{*}$, its cash holdings will never again fall below this value, given constant parameters values.

Note that the equilibrium condition (6) implies that $F^{\prime}\left(M^{*}\right)<1+r$, i.e. firm investment is constrained in steady state - agency concerns lead firms to pay out cash because of managerial myopia or because this reduces the amount of 'free cash' that managers might abuse. We will show below that inducing firms to reduce cash holdings further, e.g. because of intertemporal tax arbitrage, entails a first-order cost.

Since the arrival of investment opportunities is random, the path along this life-cycle will differ from firm to firm. We have depicted the average cash balances of a new firm over its first 15 periods in Fig. 2. As can be seen, almost all new firms in our example have reached the mature stage with $M_{t}=M^{*}$ after 10 periods.

Before proceeding to our analysis of changes in dividend taxation, let us note that our assumptions regarding investment opportunities, capital stock, access to capital markets, and incentives for dividend payments have been made mainly for analytical simplicity. There are four dimensions along which the presented model could be generalized without significantly affecting the predictions of the paper:

Firstly, instead of a binary Bernoulli variable determining an investment opportunity, we could allow for opportunities of different magnitudes, e.g. that firms face a production function of the form $\tilde{\eta}_{t} F\left(I_{t}\right)$, where $\tilde{\eta}_{t} \in[0, \in \infty)$ is a random variable. Alternatively, we could allow firms to carry unused opportunities into future periods at some cost. The assumption that postponing investment is costly corresponds to the real world, since firms are subject to e.g. changing competition, including competition from abroad, and evolving consumer tastes. As long as there is at least some cost associated with not fully seizing an investment opportunity in the period in which it is optimal to do so, changes in firms' cash balances induced by changes in dividend taxation can have real effects.

Secondly, we could add a state variable for firms' long-term capital holdings to our analysis. In the current paper we have focused on holdings of cash rather than long-term capital since cash or other liquid short-term assets are the most convenient tools for short-term intertemporal tax arbitrage. This should not be understood as suggesting that firms' long-term capital holdings are unimportant in other economic questions, but for the purpose of analyzing intertemporal tax arbitrage it keeps our model more tractable.

Thirdly, the extreme case of having no access to capital markets once an investment opportunity has materialized could easily be relaxed. We could for example assume that firms are subject to a maximum debt equity ratio, and that this is already built into the production function $F(\cdot)$ given above. Our results hold as long as internal and external finance are not or not always perfect substitutes, e.g. because there are costs to accessing capital markets. This is certainly true in the real world.

Fourthly, regarding firms' payout policy, the assumption that future dividend payments are discounted at a higher rate than the risk-free interest rate can be replaced by any other theory of why firms make dividend payments, without changing the implications of tax changes for firm investment. The only requirement is that changes in tax rates over time affect firms' marginal incentive to pay out dividends. An example for a theory of dividend payments other than agency costs is e.g. the accumulated retained earnings tax, which punishes firms for holdings excessive cash balances. As long as future changes in tax rates lead firms to alter their payout behavior at the margin, firms' cash balances and thus their investment and output will be affected. Our model is compatible with share repurchases as long as there is at least some role left to dividends, e.g. if share repurchases are capped because of IRS rules that would subject excessive repurchases to dividend taxation.

\footnotetext{
22 This yields the result that dividends are variable. In practice, dividends often show a high degree of stability related to their signaling role, as discussed e.g. in Ross (1977) or Bhattacharya (1979) and evidenced in DeAngelo and DeAngelo (1990). In our model dividends perform no signaling role. Including a coherent model in which dividends might perform such a role would greatly complicate the analysis, e.g. by requiring random shifts in the production function of the firm.
} 


\section{Changes in the dividend tax rate}

We now use the model developed in the previous section to analyze how capital constrained firms react to changes in the dividend tax rate.

\subsection{Unanticipated permanent tax changes}

For the investment decisions of mature firms, an unanticipated permanent change in the dividend tax rate in either direction is neutral. This is typical for models that follow the 'new view' of dividend taxation, since the cost of retained earnings and the returns of investment for mature firms are reduced by the same factor $1-\tau$, as we noted in the introduction. However, in accordance with the 'traditional view' elements of our model, the amount of equity that new firms raise is affected by permanent dividend tax changes:

Proposition 1. Unanticipated permanent tax changes affect the amount of equity that young firms raise, but leave the financing and investment decisions of growing and mature firms that no longer access equity markets unaffected.

Analytically, note that a firm solving problem (3) issues equity at most once, in period 0 , and if it issues equity it does not simultaneously pay dividends. Focusing on the firm's problem after period 0 , we can therefore see that dividend taxation scales the value function of the firm by a factor $1-\tau$ so that $V\left(M_{t} ; \tau\right)=(1-\tau) V\left(M_{t} ; 0\right)$. For mature firms that solve problem (3), this implies that the steady state level of cash balances and investment $M^{*}$ as well as all other financing and investment decisions are unchanged, since the linear factor $(1-\tau)$ drops out of the maximization problem. This neutrality result holds even though the market value of the firm is a declining function of the tax rate.

By the same logic, the slope of the value function is $V^{\prime}\left(M_{t} ; \tau\right)=(1-\tau) V^{\prime}\left(M_{t} ; 0\right)$, which is declining in the dividend tax rate $\tau$. Therefore the amount of equity $N^{*}(\tau)$ that new firms raise is a declining function of the tax rate as well, i.e. $N^{*}(\tau)<0$. Furthermore, in case of a tax cut from, say, $\tau_{H}$ to $\tau_{L}$ there might be some growing firms that raised a low amount of equity $N^{*}\left(\tau_{H}\right)$ under the old high tax rate, but that find it optimal to raise more equity under the new lower tax rate since their cash holdings satisfy $N^{*}\left(\tau_{H}\right) \leq M_{t}<N^{*}\left(\tau_{L}\right)$. By contrast, after unanticipated tax increases, existing firms never raise more equity. ${ }^{23}$

\subsection{Anticipated tax increases}

These results contrast strongly with the case of anticipated changes in dividend taxes, which provide incentives for all firms with sufficient cash holdings to engage in intertemporal tax arbitrage:

Proposition 2. The anticipation of a dividend tax increase induces mature firms to pay out a special dividend in the period prior to the increase, which reduces their cash holdings below the equilibrium value $M^{*}$, lowering aggregate investment for the following periods. Furthermore, as the anticipated increase approaches, the amount of equity that new firms issue progressively falls.

Throughout our discussion, let us denote by $V_{s}\left(\mathrm{M}_{t} ; \tau_{L}, \tau_{H}\right)$ the value function of a firm that expects a dividend tax increase in $s$ periods, i.e. that is subject to a low dividend tax rate $\tau_{L}$ for the next $s$ periods and then to a higher rate $\tau_{H}$ for the indefinite future. Similarly, we denote by $M_{S}^{*}\left(\tau_{L}, \tau_{H}\right)$ the firm's optimal cash balances $s$ periods before the tax increase. (Note that $V_{0}\left(M_{t} ; \tau_{L}, \tau_{H}\right) \equiv$ $V\left(M_{t} ; \tau_{H}\right)$ and $M_{0}^{*}\left(\tau_{L}, \tau_{H}\right)=M^{*}$.)

Mature firms and internally growing firms with sufficient cash balances have an incentive to engage in tax arbitrage, since shareholders can save taxes if firms pay out a higher amount of dividends in the low tax period preceding a tax increase. However, this tax arbitrage is limited by the fact that firms need cash in order to take advantage of random investment opportunities. The optimal amount of cash balances $M_{1}^{*}\left(\tau_{L}, \tau_{H}\right)$ balances these two factors off against each other: $M_{1}^{*}$ is the threshold at which the marginal value of keeping one dollar inside the firm under the high tax rate equals the value of paying out one dollar now under the low tax rate:

$$
V^{\prime}\left(M_{1}^{*} ; \tau_{H}\right)=1-\tau_{L}
$$

Beyond the threshold $M_{1}^{*}$, firms' value function $V_{1}\left(M_{t-1} ; \tau_{L}, \tau_{H}\right)$ is linear and increasing at rate $1-\tau_{L}$, since all cash in excess of $M_{1}^{*}$ is paid out and taxed at the rate $\tau_{L}$. Note that in earlier periods, i.e. in periods $t-2, t-3$ etc., internally growing and mature firms do not alter their behavior in response to the impending tax increase at time $t$ : they accumulate cash balances up to $M^{*}$ and pay out any excess, because there are no tax arbitrage opportunities. However, firm value falls in anticipation of the higher tax rate in the future (see the value functions in Fig. 3).

After firms have paid their special dividend in period $t-1$, their reduced cash holdings constrain investment, earnings, and dividends in the period $t$ of the tax hike and in the following periods, until firms have restored their optimal level of cash balances $M^{*}$ through internal savings.

\footnotetext{
23 This asymmetry reflects the asymmetry between lowering and raising equity (distributing funds to shareholders is subject to the dividend tax, raising equity is not). The marginal value of dividends to shareholders is $1-\tau$; the marginal cost to issuing equity is $1+\kappa$. Both the dividend tax and the cost involved in issuing equity thus increase the wedge between the cost of new equity and the cost of capital in the form of retained earnings.
} 


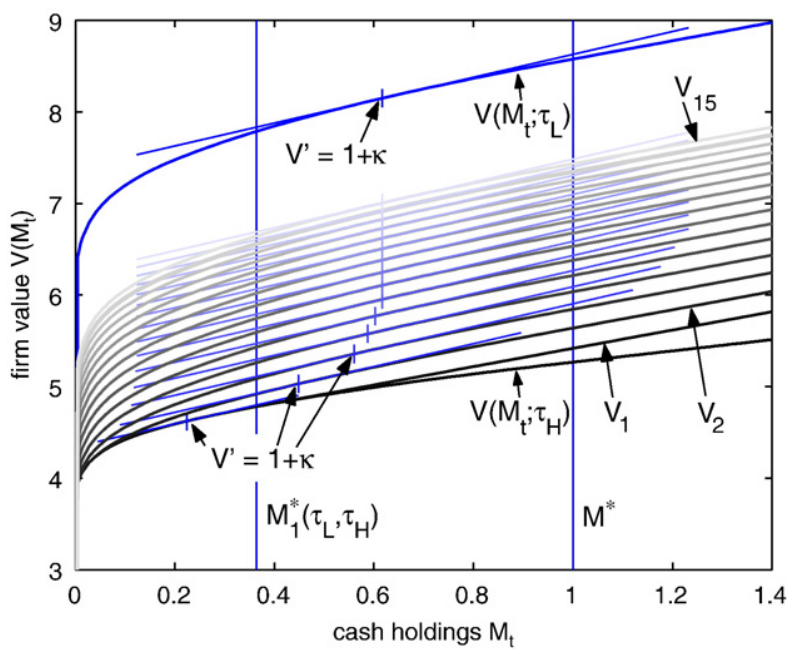

Fig. 3. Anticipated Dividend Tax Increase, Value Functions: This figure shows the value functions $\left\{V_{15}, \ldots, V_{1}\right\}$ of firms in the 15 periods prior to an anticipated dividend tax increase from $\tau_{L}=0 \%$ to $\tau_{H}=38.6 \%$. When the future tax increase is announced, the value function jumps immediately from the top curve $V\left(M_{t} ; \tau_{L}\right)$ down to $V_{15}$. Firms' value functions then move every period a small step closer to $V\left(M_{t} ; \tau_{H}\right)$.

For young firms, the cost of equity rises immediately in anticipation of a dividend tax increase, because investors are forwardlooking and expect that much of the payoff of their equity investment will occur in the future when dividend taxes are high. In the period directly before the tax increase, new firms raise the same (low) amount of new equity as if the higher tax rate was already in effect, i.e. $N_{1}^{*}\left(\tau_{L}, \tau_{H}\right)=N^{*}\left(\tau_{H}\right)$. This is because all dividends that will be paid out by these firms will be subject to the high tax rate.

To see what happens to new equity issuance in earlier periods, we need to analyze the value functions of firms in those periods. If a dividend tax hike is anticipated for time $t$, then firms' value function in period $t-s, s>0$ can be denoted iteratively as

$$
V_{s}\left(M_{t-s} ; \tau_{L}, \tau_{H}\right)=\max \left(1-\tau_{L}\right) D_{t-s}+\beta E\left\{V_{s-1}\left(\tilde{M}_{\mathrm{t}-s+1} ; \tau_{L}, \tau_{H}\right)\right\}
$$

We have depicted the value functions $V_{1}$ to $V_{15}$ for the 15 periods preceding an anticipated dividend tax hike in Fig. 3. The upmost value function in the figure represents firms that are permanently subject to the old (low) tax rate $\tau_{L}$; the lowest curve represents firms that are subject to the new (high) tax rate $\tau_{H}$ forever. If an increase in the dividend tax rate is announced $s$ periods ahead, this implies that firms' value function immediately jumps from the upmost curve down to $V_{S}\left(\tau_{L}, \tau_{H}\right)$. As can be seen in the figure, the series of value functions $V_{k}\left(\tau_{L}, \tau_{H}\right), k=s, s-1, \ldots 1$ moves every period a little closer to the final value function $V\left(M_{t} ; \tau_{H}\right)$, which will come into effect under the new dividend tax rate. The amount of equity $N_{s}^{*}\left(\tau_{L}, \tau_{H}\right)$ that new firms would issue in a given year $t-s$ is depicted as the tangent with slope $1+\kappa$ to the value function $V_{s}(\cdot)$. Analytically it can be determined by the condition $V_{s}\left(N_{S}^{*}(\cdot) ; \tau_{L}, \tau_{H}\right)=1+\kappa$. Clearly, $N_{s}^{*}(\cdot)$ decreases the closer the economy comes to the dividend tax increase.

The effects of an anticipated tax increase on new firms thus follow what is predicted by the traditional view of dividend taxation, since the marginal source of funds for new firms is equity markets. For this category of firms, our findings are also consistent with Alvarez et al. (1998) who discuss how firm investment reacts to the anticipation of tax policy changes.

An important implication of our results is that a tax cut that is scheduled to expire after a few periods does not raise the amount of investment by much and has a significantly smaller impact on the cost of equity of new firms than what would be predicted from analyzing a permanent tax cut of identical magnitude.

\subsection{Probabilistic tax increases}

Firms react in a similar way if there is uncertainty about whether a dividend tax increase will occur in a future period. Such a situation can arise for example if a dividend tax cut has been implemented in the past and firms expect (e.g. for political economy reasons or because of large fiscal deficits) that the tax cut will be undone in a future period.

Suppose that there is a constant probability $\pi$ each period that the prevailing dividend tax rate $\tau_{L}$ will rise to $\tau_{H}$. Then mature firms reduce their cash balances to $M_{\pi}^{*}\left(\tau_{L}, \tau_{H}\right)<M^{*}$ while the low tax rate is in effect. $M_{\pi}^{*}$ is the point at which the expected stochastic tax savings from paying out a higher dividend now (left-hand side) equal the cost of forgoing a potential investment opportunity next period because of cash constraints (right-hand side):

$$
1-\tau_{L}=\pi V^{\prime}\left(M_{\pi}^{*} ; \tau_{H}\right)+\beta(1-\pi)\left(1-\tau_{L}\right)\left[p F^{\prime}\left(M_{\pi}^{*}\right)+(1-p)(1+r)\right] .
$$

Naturally, mature firms depress their cash balances more the greater the probability of the tax increase and the larger the expected difference in tax rates. Young firms that raise new equity are affected in a similar way to what we discussed in the previous subsection. A direct implication of the observation that $M_{\pi}^{*}\left(\tau_{L}, \tau_{H}\right)<M^{*}$ is the following: 
Corollary 1. If there is uncertainty about a future dividend tax increase, investment by mature firms can be increased by raising dividend taxes immediately.

What is perhaps even more striking is that whether the government raises or leaves the tax rate (permanently) unchanged, firm investment and tax revenues will increase. Once the uncertainty about a possible dividend tax increase is resolved (in either direction), mature firms increase their cash holdings back to $M^{*}$.

\subsection{Anticipated tax cuts}

We next investigate a dividend tax cut from $\tau_{H}$ to $\tau_{L}$ that is anticipated $s$ periods ahead. The general idea is that for new firms, the cost of capital falls in anticipation of the tax cut; for mature firms the anticipated tax cut creates an opportunity to engage in intertemporal tax arbitrage by postponing dividend payments:

Proposition 3. An anticipated dividend tax cut leads to a temporary increase in investment by internally growing and mature firms that engage in tax arbitrage while the old (high) tax rate is in effect. Furthermore, it increases the amount of equity that new firms raise.

Mature firms can delay dividend payments to later periods and thereby save on dividend taxes by temporarily increasing their cash holdings above $M^{*}$. Specifically, they keep all their cash earnings on the balance sheet for $k$ periods preceding a tax cut, i.e. $M_{s}=\infty$ for $s=1, \ldots k$, where $k$ is the largest integer such that $1-\tau_{H}<\left(1-\tau_{L}\right)[\beta(1+r)]^{k}$. During these $k$ periods, paying dividends in the future at the lower tax rate is - despite the high discount rate - more favorable to investors than paying out immediately under the high tax rate, and therefore firms pay zero dividends and retain all earnings. ${ }^{24}$ In period $k+1$ before the tax cut, firms accumulate cash balances up to $M_{k+1}^{*}>M^{*}$, which is defined by

$$
\beta\left[p F^{\prime}\left(M_{k+1}^{*}\right)+(1-p)(1+r)\right]=\frac{1-\tau_{H}}{1-\tau_{L}} \cdot \frac{1}{[\beta(1+r)]^{k}} .
$$

We noted earlier that, because of agency considerations, firms' equilibrium cash holdings $M^{*}$ and their steady state investment $I_{t}=M^{*}$ is below the optimum investment $I^{*}$ in a neoclassical world without capital constraints, as defined by $F^{\prime}\left(I^{*}\right)=1+r$. Since postponing dividends raises firm cash holdings, it enables firms to more fully take advantage of investment opportunities. Specifically, arbitraging firms invest all their cash holdings up to $I^{*}>M^{*}$ when an investment opportunity arrives and keep the rest in cash, i.e. they are subject to constant returns to scale above $I^{*}$, earning the risk-free return $r$.

In period $k+1$ before the tax cut, optimal cash holdings are $M^{*}<M_{k+1}^{*}<I^{*}$ - firms increase cash holdings above the long-run steady state $M^{*}$, but are still cash-constrained in equilibrium because the incentives for tax arbitrage are only weak. They pay out any cash holdings in excess of $M_{k+1}^{*}$. After that, no further dividend payment is made for the next $k$ periods, i.e. until after the tax cut. Once the cut has been implemented, all the accumulated excess cash holdings $M_{t}-M^{*}$ are distributed to shareholders in the form of a special dividend at the low dividend tax rate $\tau_{L}$.

If a dividend tax cut is expected to occur more than $k+1$ periods in advance, then the payout and investment policies of existing firms are unaltered up until period $k+1$. However, share prices rise immediately in anticipation of the tax cut.

New firms realize that most of their dividend payments will be made in the future when taxes are low; therefore firms' value function jumps immediately and continues to move up until the tax cut is enacted. We have illustrated an example of the 15 periods before an anticipated cut is enacted in Fig. 4. The bottom line depicts firms' value function under the old high-tax regime; the top line represents the value function after the tax cut was enacted. The curves in between illustrate how firms' valuation gradually approaches the after-tax cut valuation.

The tangents with slope $1+\kappa$ to the various value functions $V_{15}, V_{14}$, etc. (marked with vertical ticks) indicate the amounts of equity that new firms issue in the respective periods. In the period $t-1$ immediately preceding a tax cut, firms issue the same amount of equity $N_{1}^{*}\left(\tau_{H}, \tau_{L}\right)=N^{*}\left(\tau_{L}\right)$ as if the cut was already enacted, since all their future dividends will be taxed at the lower rate. In earlier periods, the optimal amount of new equity continually rises, i.e. $N_{s-1}^{*}>N_{s}^{*}$. Young firms with low cash holdings $M_{t-s}<N_{s}^{*}\left(\tau_{H}\right.$, $\left.\tau_{L}\right)$ thus have an incentive to access equity markets again, and possibly multiple times, whenever their internal cost of capital is higher than the new cost of equity, given the impending dividend tax cut. ${ }^{25}$

\subsection{Probabilistic tax cuts}

If there is uncertainty about whether a dividend tax cut will occur in a future period, similar conclusions hold. An example for this situation occurred in 2002, when political parties were discussing the possibility of a reduction in the dividend tax rate.

Analytically, if firms expect a dividend tax cut from $\tau_{H}$ to $\tau_{L}$ with a probability of $\pi$ in every time period until the tax cut is realized, they accumulate higher cash balances up to a level of $M_{\pi}^{*}\left(\tau_{H}, \tau_{L}\right)>M^{*}$ while there is uncertainty. $M_{\pi}^{*}$ is defined by

$$
\begin{array}{ccc}
\beta\left(1-E \tau_{t+1}\right)\left[p F^{\prime}\left(M_{\pi}^{*}\right)+(1-p)(1+r)\right]=1-\tau_{H} & \text { if } & 1-\tau_{H}>\beta(1+r)\left(1-E \tau_{t+1}\right) \\
M_{\pi}^{*}=\infty & \text { if } & 1-\tau_{H} \leq \beta(1+r)\left(1-E \tau_{t+1}\right)
\end{array}
$$

\footnotetext{
${ }^{24}$ For dividend tax cuts that are small in comparison to the equity premium, it is possible that $k=0$.

25 This is an important asymmetry to anticipated tax increases as discussed in subsection 3.2: firms cannot undo equity issues when the cost of equity rises in reaction to an anticipated tax increase.
} 


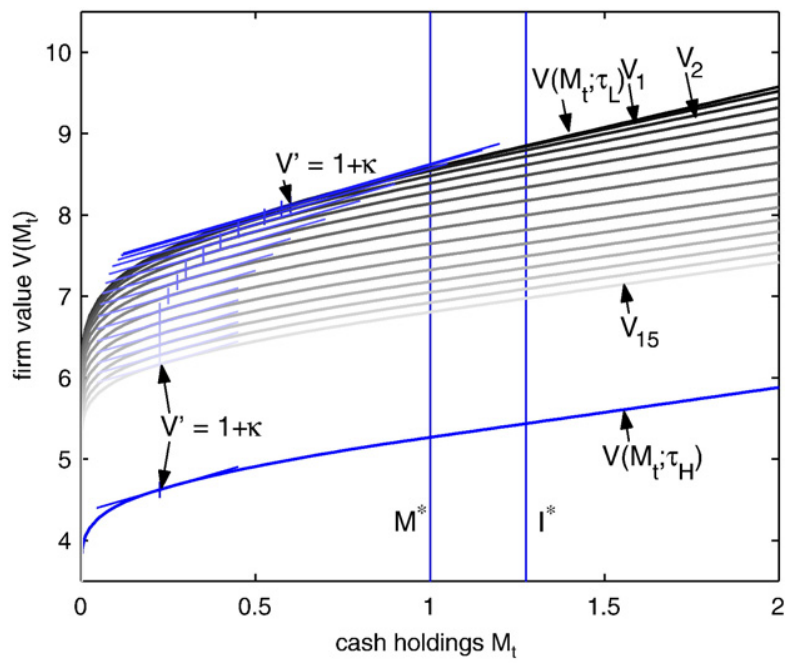

Fig. 4. Anticipated Dividend Tax Cut, Value Functions: The value functions $\left\{V_{15}, \ldots, V_{1}\right\}$ of firms in the 15 periods prior to an anticipated dividend tax cut move closer and closer to the value function $V\left(M_{t} ; \tau_{L}\right)$ prevailing under the new dividend tax rate. The amount of equity that new firms issue, indicated by the tangent with slope $1+\kappa$ to each value function, rises.

where $E \tau_{t+1}=(1-\pi) \tau_{H}+\pi \tau_{L}$ is the expected dividend tax rate next period. In other words, firms reduce their dividend payments and increase their cash holdings in order to take advantage of the expected lower dividend tax in the future. If the tax cut is likely or large enough, as described by the second inequality, firms will not pay any dividends until the tax cut has materialized. Instead, they would be willing to accumulate arbitrarily large cash balances.

Corollary 2. If there is uncertainty about whether there will be a tax decrease, it pays the government to postpone resolving that uncertainty (either way). In the interim, investment is higher.

\subsection{Temporary dividend tax changes}

Essentially, an unanticipated temporary change in dividend taxes is equivalent to an unanticipated change in one direction followed by an anticipated change in the reverse direction at a later point in time.

Let us first focus on temporary dividend tax cuts. Assume that a high dividend tax rate of $\tau_{H}$ is unexpectedly reduced to $\tau_{L}$ for $k$ periods, after which it returns to $\tau_{H}$. As discussed before, the unanticipated reduction in the tax rate increases the value of all firms. For new firms, this increases the amount of equity that they raise, but it does not have any effects on the behavior of mature firms.

However, note that both the increase in stock prices and in the amount of equity that new firms issue is strongly mitigated by the fact that a dividend tax rise after $k$ periods is anticipated. Fig. 3 reveals that firms' value functions for the periods preceding a typical tax hike are actually much closer to $V\left(M_{t} ; \tau_{H}\right)$, i.e. the lowest line in the figure, than to $V\left(M_{t} ; \tau_{L}\right)$, the highest line that would correspond to a permanent tax cut. In other words, the positive effects of lower dividend taxes in terms of a lower cost of equity is strongly reduced by the fact that a dividend tax hike in a future period is impending. The reason is that young firms usually do not pay out dividends in the first few years of their existence, but only once they have accumulated their steady state holdings of cash $M^{*}$. We can thus conclude that temporary dividend tax cuts reduce the marginal cost of equity $V^{\prime}\left(M_{t}\right)$ mostly for those firms that do not need it (mature firms), but hardly affect the marginal cost of equity for new firms that need to access capital markets. In the extreme case of a one-period temporary tax cut, this leads to the following result.

Proposition 4. The effects of an unanticipated one-period dividend tax cut on aggregate investment are unambiguously negative.

New firms do not raise more equity than if the tax rate had been kept at $\tau_{H}$, since taxes will be back at their earlier level when they make their first distributions. At the same time, because of arbitrage considerations, internally growing and mature firms pay out a special dividend to reduce their cash holdings to $M_{1}^{*}\left(\tau_{L}, \tau_{H}\right)$, and their cash balances will be lower for a number of periods until firms have recovered their optimum, $M^{*}$.

The opposite conclusions hold for a temporary dividend tax increase. While the amount of equity that new firms issue during the high tax period would fall, firms hold higher cash balances than $M^{*}$ in anticipation of the impending dividend tax cut, and this allows them to invest higher amounts. Again, the extreme case of an unanticipated one-period increase would have unambiguously positive effects on aggregate investment, though only for one period.

\section{Aggregate investment and output}

This section investigates the effects of dividend tax policy on aggregate investment, summing up across all firms in the economy. For a firm of age $a$ that was started $a$ periods ago, we define average investment as $\bar{I}_{a}:=p E\left[I_{a}\right]$, the probability of receiving 

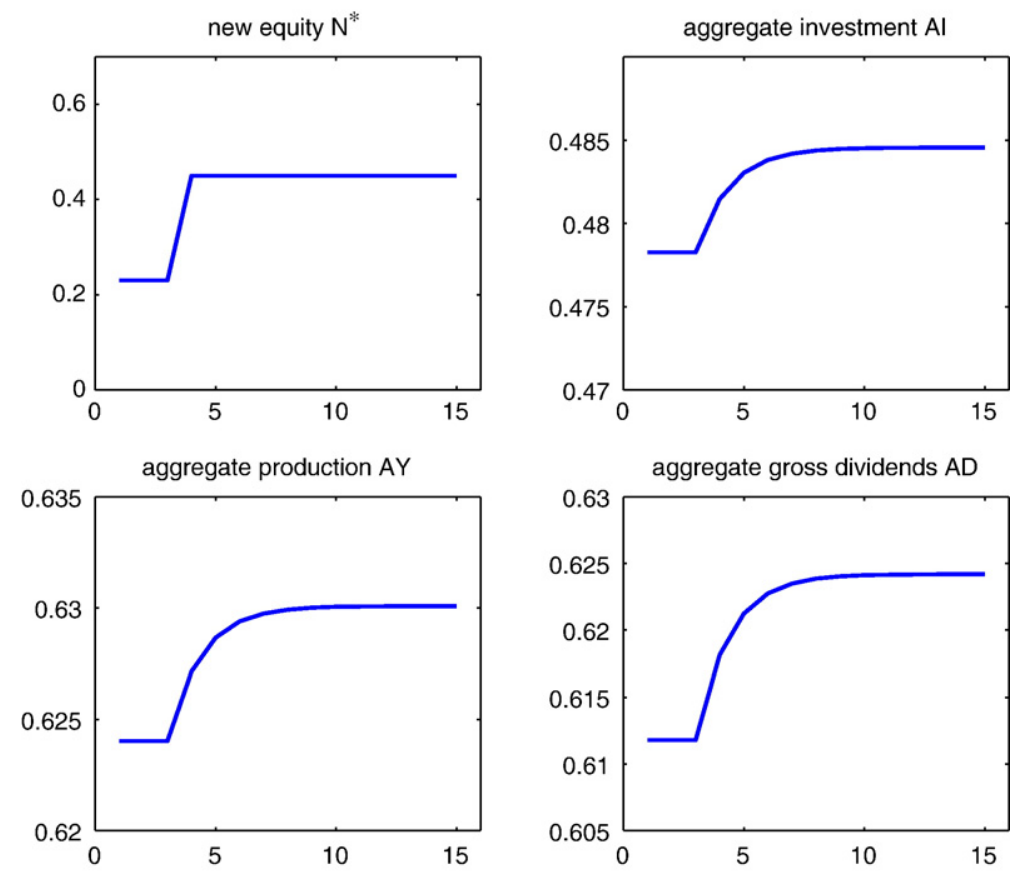

aggregate net dividends $(1-\tau) A D$

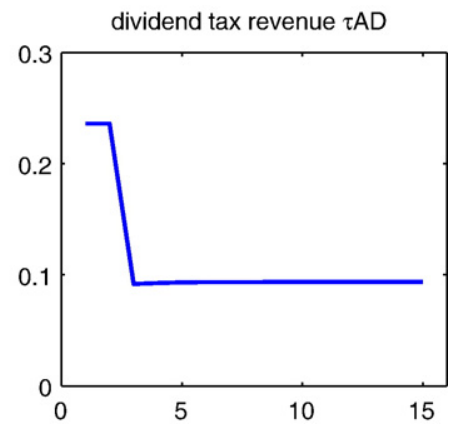

Fig. 5. Unanticipated Dividend Tax Cut: After an unanticipated dividend tax cut from 38.6\% to $15 \%$ in period 4 , the amount of new equity $N^{*}$ that new firms issue rises significantly. However, aggregate investment $A I$, production $A Y$, and gross dividend payments $A D$ increase only modestly. The redistributory effect of the tax change, on the other hand, is very strong.

an investment opportunity times the amount that would be invested. Evidently, this entails that $\bar{I}_{0}=p N^{*}$ and $\bar{I}_{a}=p M^{*}$ for all $a \geq T$, where $T$ is the number of years after which all firms of vintage $a$ have reached their steady state cash holdings $M^{*}$. Similarly, we define expected net output and expected dividend payments by a firm of age $a$ as $\bar{Y}_{a}:=p E\left[G\left(I_{a}\right)\right]$ and $\bar{D}_{a}:=E\left[D_{a}\right]$.

Assume that at any given time $t$ the economy consists of a mass $z_{t-1}$ of existing firms, and a mass $\Delta z_{t}=\gamma z_{t-1}$ of new firms is started, yielding a total of $z_{t}=(1+\gamma) z_{t-1}$. Firms are indexed by $i$ and follow the maximization problem and the resulting rules described in the previous sections. The arrival of investment opportunities is independent among firms, yielding deterministic values for all macroeconomic variables.

In steady state the fraction of firms at a given stage of development, say age $a$, is then constant at $\frac{\gamma}{(1+\gamma)^{a+1}}$. However, the total mass of firms is increasing, reflecting growth in the economy. At time $t$ the total mass of firms of age $a$ is $\frac{\gamma}{(1+\gamma)^{a+1}} z_{t}$. Aggregate investment $A I_{t}$ at time $t$ can then be expressed as

$$
A I_{t}=\int_{0}^{z_{t}} p I_{t, z} d z=z_{t-T} \bar{I}_{T}+\cdots+\Delta z_{\mathrm{t}} \bar{I}_{0}=z_{t}\left[\frac{\bar{I}_{T}}{(1+\gamma)^{T}}+\sum_{\mathrm{a}=0}^{\mathrm{T}-1} \frac{\gamma \bar{I}_{a}}{(1+\gamma)^{a+1}}\right]
$$

By the same token, aggregate output $A Y_{t}$ and aggregate dividend payments $A D_{t}$ are

$$
A Y_{t}=z_{t}\left[\frac{\bar{Y}_{T}}{(1+\gamma)^{T}}+\sum_{a=0}^{\mathrm{T}-1} \frac{\gamma \bar{Y}_{a}}{(1+\gamma)^{a+1}}\right] \text { and } A D_{t}=z_{t}\left[\frac{\bar{D}_{T}}{(1+\gamma)^{T}}+\sum_{\mathrm{a}=0}^{\mathrm{T}-1} \frac{\gamma \bar{D}_{a}}{(1+\gamma)^{a+1}}\right]
$$



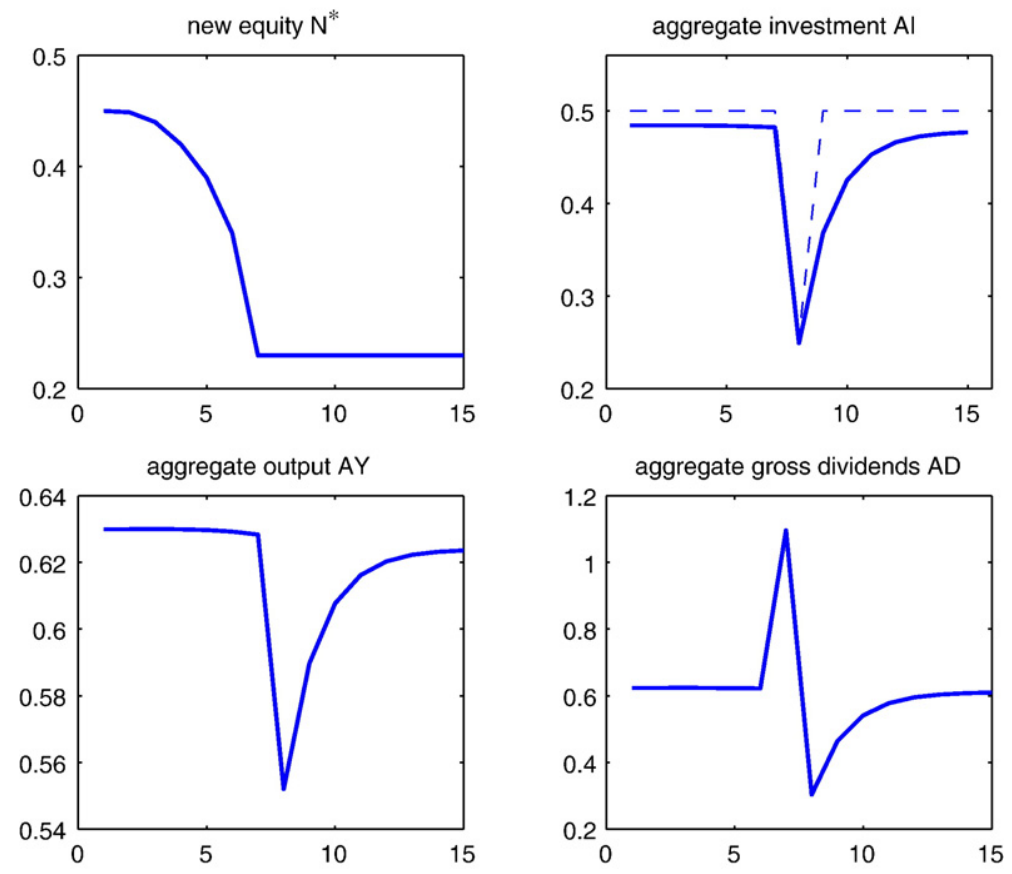

aggregate net dividends $(1-\tau) A D$

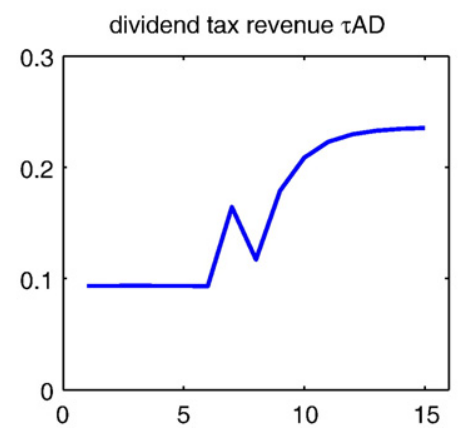

Fig. 6. Anticipated Dividend Tax Increase: The amount of equity $N^{*}$ that new firms issue starts falling when the tax increase is announced, causing a small decline in aggregate investment, output, and dividend payments. In the period preceding the tax increase (period 7), firms pay out a special dividend, reducing aggregate investment $A I_{t}$, output $A Y_{t}$ and dividends $A D_{t}$ for periods to come. (The dotted line in the graph for investment represents the path of firms' optimal cash holdings $M^{t}$. It always lies above $A I$ since not all firms are in steady state.)

Let us use this setup to simulate the impact of dividend tax policy on aggregate variables. Note that our analysis is partial equilibrium in the sense that we take the interest rate as given and do not allow for e.g. offsetting monetary policy actions. ${ }^{26}$ As we argued earlier, this may be justified if the economy is open to international capital flows, which break the link between domestic saving and investment and determine interest rates exogenously. In reality, some of the dividends paid out may be re-invested in the domestic economy. But empirically, there is some question about the extent to which this may be so. ${ }^{27}$ Since dividend taxes are only a small part of government revenue, we furthermore disregard the effects of dividend taxation on the government's budget position.

Following Mehra and Prescott (1985) we chose $\beta=0.93$ and $r=1 \%$. In order to replicate a typical growth rate of the economy we calibrated $\gamma=3 \%{ }^{28}$ For the other structural parameters we used values of $\alpha=1 / 2$ and $p=1 / 2$, and $A$ was chosen so that $M^{*}=1$. However, our results are robust to alternative calibrations.

\footnotetext{
${ }^{26}$ Even if there is a feedback effect on interest rates (see e.g. the reasoning in Section 3.2. of Sinn, 1991), all the effects that we discuss are still present, though they are mitigated by endogenous adjustments in the interest rate.

${ }^{27}$ For example, if we assume that the Fed sets interest rates so as to maintain a given level of GDP, and if there are some individuals who are cash constrained (à la Stiglitz-Weiss) and spend some of the dividends they receive, then consumption will be higher and investment lower: in equilibrium, not all of the money will have "re-circulated" back into investment. More generally, our qualitative results hold as long as the marginal propensity to invest (directly or indirectly) of the recipients of dividends is lower than had the money remained inside the firm.

${ }^{28}$ Empirically, the value of new equity issued fluctuates wildly from year to year, but $\gamma=3 \%$ is a reasonable approximation to the average long-run amount of equity issuance.
} 

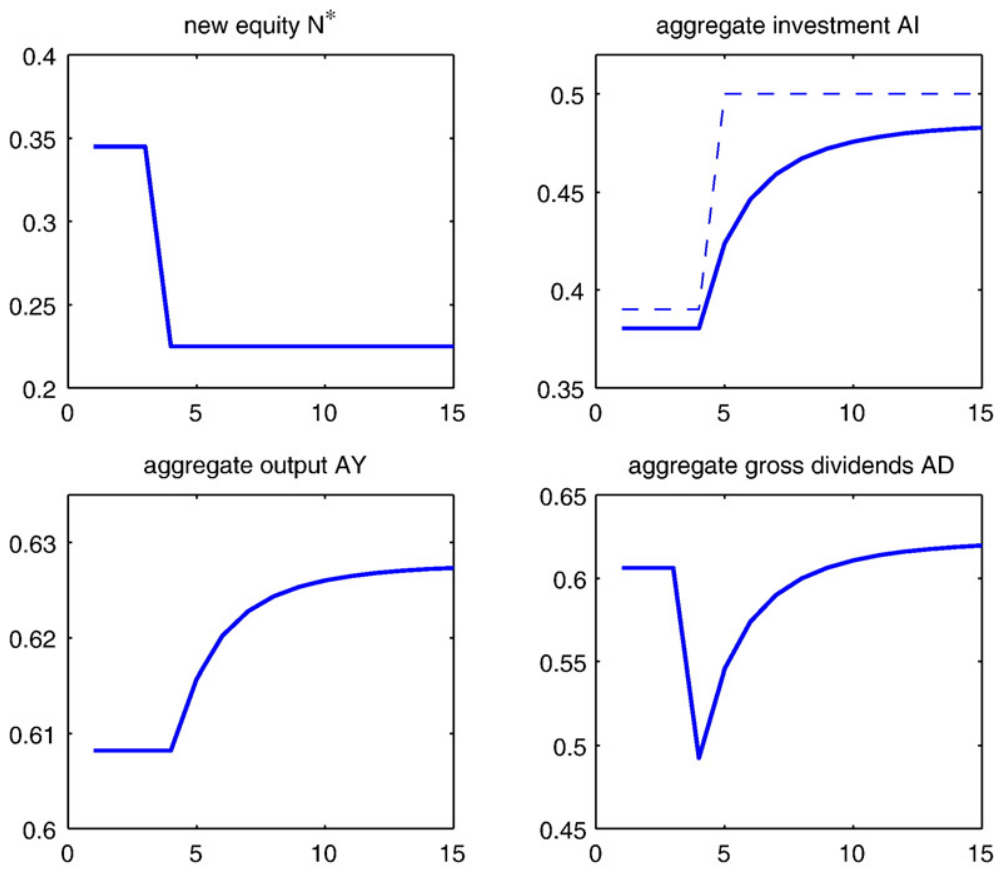

aggregate net dividends $(1-\tau) A D$
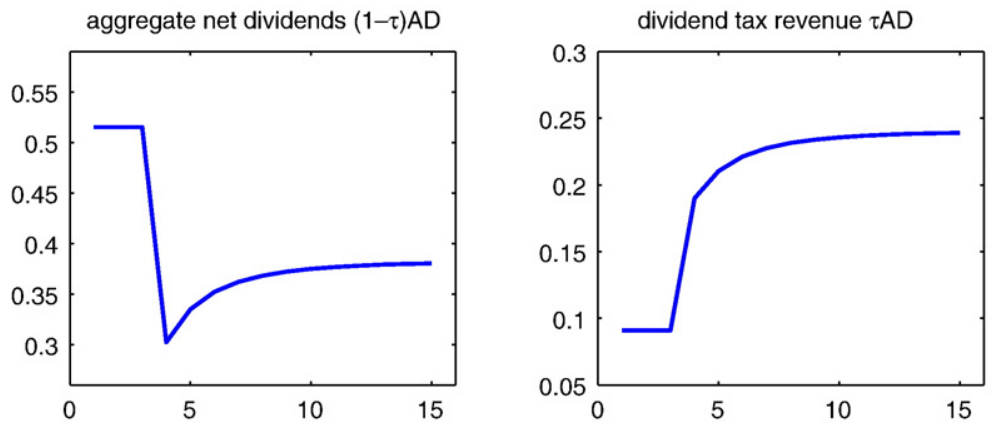

Fig. 7. Risk of Dividend Tax Increase: In periods 1 to 3 firms anticipate that there is a $\pi=25 \%$ risk of a dividend tax hike from $15 \%$ to $38.6 \%$. This reduces mature firms' cash reserves and depresses aggregate investment. The tax increase is enacted in period 4, and firms' optimal cash reserves (the dotted line in the upper right pane) revert to $M^{*}$. Aggregate investment increases even though new firms issue less equity $N^{*}$ under the higher dividend tax rate.

\subsection{Aggregate effects of unanticipated dividend tax changes}

We showed in the previous section that the behavior of internally growing and mature firms (and hence their contribution to investment) is unaffected by dividend taxes. However, new firms issue less equity the higher the dividend tax rate and therefore take longer to reach the mature stage. This reduces aggregate investment, but since only a small fraction of investment in the economy is performed by new firms that access equity markets, the aggregate effect of unanticipated dividend tax changes is small.

Proposition 5. In response to unanticipated changes in dividend taxes, aggregate investment $A I_{t}$, aggregate output $A Y_{t}$ and aggregate dividend payments $A D_{t}$ in the economy are lower the higher the tax rate.

We depict an example of an unanticipated reduction of a $\tau_{H}=38.6 \%$ dividend tax to $\tau_{L}=15 \%$ in Fig. $5 .{ }^{29}$ The tax cut occurs unexpectedly in period 4 and immediately raises the amount of new equity $N^{*}$ that new firms issue. Since the optimal amount of cash balances $M^{*}$ for mature firms remains unchanged, the average firm in the economy has only slightly higher cash balances, as a result of the higher $N^{*}$. As a result, aggregate investment $A I$, production $A Y$, and gross dividend payments $A D$ increase very modestly. However, the distribution of firms' dividends changes significantly: shareholders net dividend receipts $(1-\tau) A D$ increase steeply; the government's revenue from dividend taxation $\tau A D$ falls sharply. Thus the redistributory effect of changes in dividend taxation is an order of magnitude stronger than any efficiency effects. ${ }^{30}$ In our simulation model, the described cut of a $38.6 \%$

\footnotetext{
${ }^{29}$ We have normalized all aggregate variables in this figure as well as in the following figures by $z_{t}$ in order to distinguish the effect of tax policy from the general growth of the economy.

${ }^{30}$ If the lower government revenue forces a reduction in public spending and if there is a multiplier associated with government expenditure, then the dividend tax cut would potentially have a strongly negative effect on output.
} 

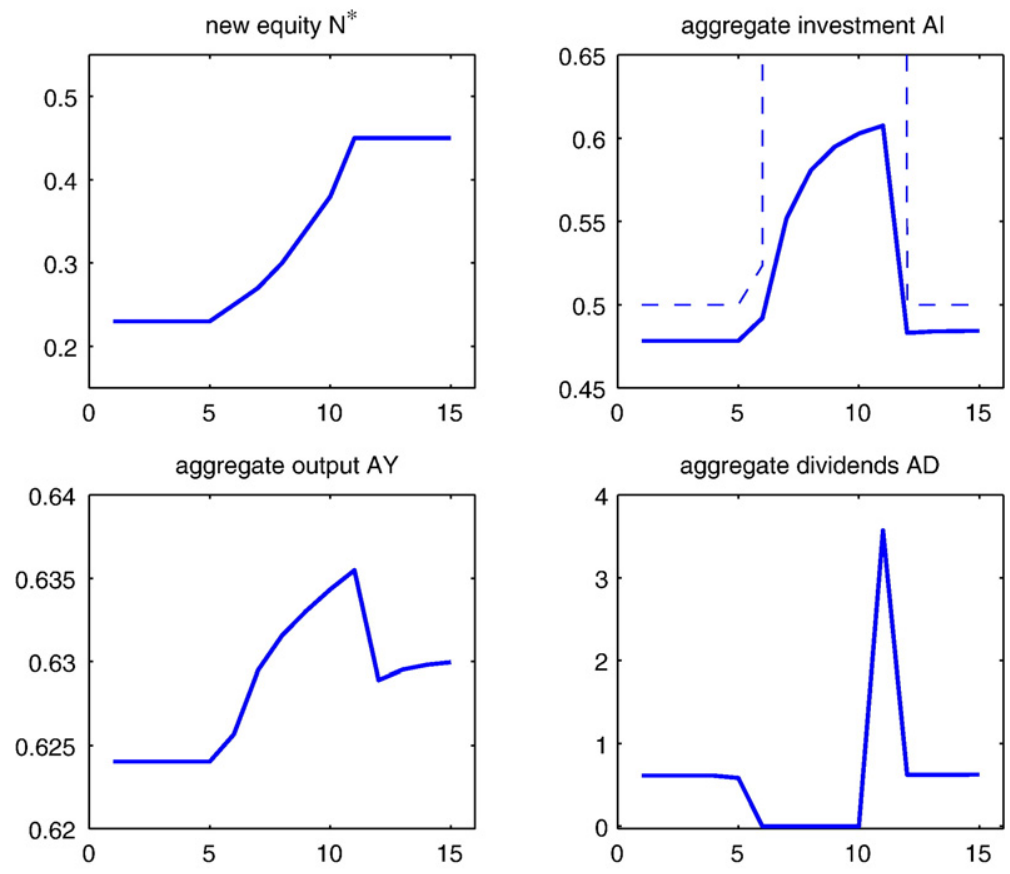

aggregate net dividends $(1-\tau) A D$
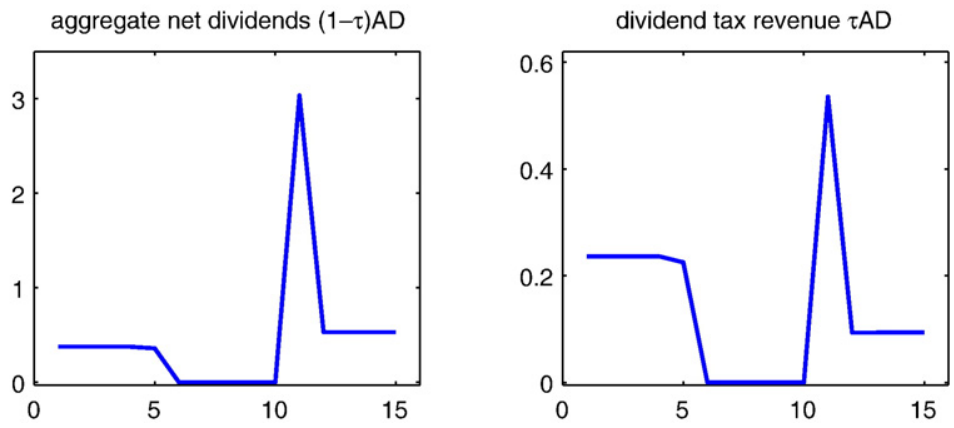

Fig. 8. Anticipated Dividend Tax Cut: At $k=5$ periods before an anticipated dividend tax cut from $38.6 \%$ to $15 \%$, firms stop paying dividends $A D$ and accumulate cash instead. This increases the aggregate amounts of investment $A I$ and production $A Y$ that firms can engage in. After the tax cut is enacted, here in period 11 , firms pay out all their excess cash and return to the steady state. The amount of equity that new firms issue, $N^{*}$, increases as a result of the tax cut, but the overall effect on aggregate investment once the cut has materialized is lower than in the periods of anticipation.

dividend tax increased aggregate investment, output, and dividends only by $1.3 \%, 0.9 \%$ and $2 \%$ respectively. Recall in this context that due to various tax deductions, the estimated effective dividend tax rate in the US economy is actually much lower than the nominal rate.

\subsection{Aggregate effects of an anticipated tax increase}

As discussed in the previous section, the results for an anticipated tax change differ substantially. In Fig. 6 we have depicted an example of a tax increase from $\tau_{L}=15 \%$ to $\tau_{H}=38.6 \%$ that is anticipated to occur in period 8 . The effects on aggregate macroeconomic variables are twofold: Firstly, new firms issue less and less equity both in the periods leading up to the increase and under the new tax rate, reducing their investment and prolonging the time for them to reach the steady state. Secondly, all mature firms pay out a special dividend in the period immediately preceding the tax increase, reducing their investment for periods to come. Since most firms in the economy are mature, this second effect is much more pronounced than the first one. As can be seen from the two graphs at the bottom, the redistributory effects of the tax increase are even stronger than the direct effects on investment.

Fig. 7 depicts an example of the case that firms expect a dividend tax increase with a constant probability of arrival of $\pi=25 \%$ in each of the following periods. This reduces their optimal cash balances to $M_{\pi}^{*}$ and depresses aggregate investment. In period 4, the tax increase is enacted, and firms' optimal level of cash holdings reverts to $M^{*}>M_{\pi}^{*}$, which increases investment activity in the economy. However, the amount of equity that new firms issue decreases in period 4 as a result of the higher dividend tax rate. 


\subsection{Aggregate effects of an anticipated tax cut}

An example of firms' reaction to an anticipated dividend tax cut is given in Fig. 8: Starting from period 1 agents foresee that dividend taxes will fall from $\tau_{H}=38.6 \%$ to $\tau_{L}=0 \%$ in period $t=11$. The amount of equity that new firms issue slowly increases between periods 1 and 11 .

Mature firms' payout policy is unchanged up to period 5, in which they reduce their dividend payments. From period 6 to period 10 , firms make no dividend payments and accumulate all of their earnings. This allows them to invest more in case an investment opportunity arises, but only up to a maximum of $I^{*}$, since the marginal product of capital turns below the risk-free interest rate after this threshold. Aggregate investment $A I$ and output $A Y$ are thus significantly above their long-run equilibrium value.

In period 11, when the tax cut is enacted, mature firms pay a special dividend, which returns them to the steady state. New firms can now issue a slightly larger amount of equity, but as the figure illustrates, aggregate investment and output are lower once the anticipated dividend tax cut has materialized than during the periods when it was expected.

A comparison of this example with the unanticipated tax increase in Fig. 5 illustrates that the macroeconomic effects of anticipated tax changes are by an order of magnitude higher than that of unanticipated changes. We can derive five very clear implications for policymakers from this observation:

1. Unanticipated changes in dividend taxes have only insignificant macroeconomic effects, but strong redistributory consequences.

2. If policymakers want to increase dividend taxes or if firms expect an increase in the future, it is better to enact it immediately.

3. If policymakers want to reduce dividend taxes or if firms expect a reduction in the future, back-load the tax cut and keep firms waiting.

4. Unanticipated temporary dividend tax cuts are equivalent to an immediate unanticipated tax cut followed by an anticipated tax increase at a later time; they have an overall negative effect on investment and output.

5. Conversely, unanticipated temporary dividend tax increases have an overall positive effect on investment and output.

\section{Political economy of dividend tax changes}

In democratic societies, there are frequent changes in party rule, and parties often adjust the levels of tax rates when they come to power. The effect of any dividend tax policy thus has to be analyzed in a dynamic context that explicitly takes the possibility of regime changes and future changes in tax policy into account. This is of even greater importance, since we have shown in the previous sections that the level of dividend taxation itself does not have strong macroeconomic effects, but that anticipated changes in the tax rate can introduce significant distortions into the economy.

Even if the party in power succeeds in defining a "clear" policy, ${ }^{31}$ the governing party cannot, in a democracy, prevent the opposition from suggesting that, should they get elected, there will be a change in policy. Indeed, contestable politics focuses on changing policies, and this is desirable. It is hard to envision a politics in which each party claims that it will simply continue with the policies of its rivals.

Let us assume an economy with two parties, conservatives and social democrats, that have different preferences over tax rates. When conservatives are in power, private agents anticipate that tax rates will rise as soon as social democrats will come to power. Under the hypothesis that party rule is governed by a Markov process, this is similar to the model of Section 3, where we have shown that firms pay out higher dividends and hold lower cash balances if there is a risk of tax increases. As a result, they are comparatively constrained in their investment behavior when an investment opportunity arises. These effects of tax arbitrage are stronger, the larger the expected dividend tax increase.

In our analysis of the previous sections, we have taken tax rates as given. But we could also derive the non-cooperative Nash equilibrium in the game between two political parties. Because of their different preferences, the social democrats impose higher tax rates than the conservatives. It is easy to see that this fact leads the conservatives to adjust the optimal tax rate that they impose: The larger the expected tax increase when conservatives lose power, the more incentive firms have to engage in intertemporal arbitrage and to make large payouts during conservative rule, which constrain their investment and contract output under the conservative regime. If conservatives put a high weight on investment and output under their regime, they will therefore implement a higher tax rate than what would be optimal if they could legislate tax rates permanently. This raises investment under their regime relative to the opposition's regime.

When social democrats are in power, on the other hand, firms anticipate a tax cut the next time that conservatives enter government. As shown in Section 5, they pay out lower dividends and accumulate higher cash balances than under conservative rule, which allows them to invest more when an investment opportunity arises. This effect is stronger the larger the expected tax cut. The social democrats know that (firms know that) when the conservatives seize power, taxes will be lower. If social democrats also place a large weight on investment and output in their preferences, they also have an incentive to raise dividend taxes so as to maximize the expected tax cut. As a result, both parties exhibit a bias towards "excessive" dividend taxation. ${ }^{32}$ We present a more detailed analysis of this political game as well as a set of more general implications for the analysis of public policies in contestable democracies in Korinek and Stiglitz (2008).

\footnotetext{
31 And many have failed to do so - as an extreme example, there were three major tax "reforms" under Reagan in 5 years.

32 By contrast, if parties placed a large weight on dividend payouts under their regime, e.g. because they value the government revenue derived from dividend taxation or the resulting income stream to investors, both parties would exhibit a bias towards inefficiently low tax rates: each party would lower tax rates competitively so as to induce firms to pay out more under its regime.
} 


\section{Conclusions}

This paper has investigated the dynamic effects of dividend taxation on macroeconomic variables such as investment and output using a life cycle model of capital constrained firms. Firms in our model start out by issuing equity, then they accumulate more funds by retaining their earnings, i.e. internal saving, and when they reach the mature stage they pay out dividends.

Using quantitative simulations we find that unanticipated tax changes have rather small effects on aggregate investment, since they only impact how much equity new firms issue and since new firms are only a small part of the economy. However, anticipated or temporary dividend tax changes create opportunities for intertemporal tax arbitrage for growing and mature firms and can significantly distort both firm-level and aggregate corporate cash holdings and investment decisions.

For example, an unanticipated temporary dividend tax cut, such as the one enacted in the United States in 2003 and extended in 2006, can be seen as an unanticipated tax cut, followed by an anticipated tax increase at the expiration of the law. We argued that such a temporary reduction in the dividend tax rate induces mature firms to make large payouts while dividend taxes are low and can have strongly negative effects on aggregate investment.

While many of the proponents of tax cuts argued that the 2003 and 2006 cuts would increase investment and growth, our analysis suggests that the cumulative effect of these measures might actually be to reduce aggregate investment because of the distortions introduced by tax arbitrage in the periods after the tax cuts are expected to expire. Future empirical work should therefore examine how firm investment responds in the periods surrounding anticipated dividend tax changes, especially among mature firms that have the greatest ability to engage in intertemporal tax arbitrage.

We also found that uncertainty about whether or how long a government will keep a low dividend tax rate in place can lead to a phenomenon similar to the peso problem: firms assign a certain probability to a dividend tax increase, which leads them to pay out more cash than optimal in every period until the uncertainty is resolved. In such a situation, it could be optimal to bring the tax increase forward - this would immediately increase aggregate investment. Incumbent governments can only control what they do: they cannot control what the opposition promises, or what firms and investors believe the opposition might do. Our analysis suggests that governments that ignore these dynamic effects do so at their peril.

This paper has explored an important set of dynamic interactions. These are pervasive in many other arenas of policy. Our paper thus has broader implications for the conduct of policy analysis and political economy in contestable democracies. The question should not be, what is the best "permanent" policy, but rather, given the policy preferences of the opposition, and the responses of agents within the economy, what is the best policy each party can pursue when it is in office; and what kind of deals can be struck between different parties to achieve efficient cooperative outcomes.

\section{Appendix A. Model of managerial myopia}

The model presented in Section 2 of this paper emphasizes that there are agency problems between the owners and managers of firms. We assumed that as a result, firm managers maximize the expected discounted value of future dividend flows using a discount rate that includes a premium reflecting these agency factors, i.e. that managers of firms are myopic. This appendix illustrates how such a discrepancy in discount rates can be motivated.

We assume that there are informational asymmetries between shareholders and managers, and as a result a manager's effort is not perfectly observable to shareholders. In order to motivate managers to exert effort in such an environment, their compensation needs to be performance-based, as discussed by e.g. Baker et al. (1988). To capture the effects of incentive pay we follow Chetty and Saez (2007) in assuming that managers hold a fraction $\alpha$ of their company's stock. However, managers do not serve in their job forever. For simplicity, we assume that they face an exogenous separation probability $s$ every period, and that they no longer participate in the company's earnings and dividends after their departure. ${ }^{33}$ As a result, managers discount dividend payments every period by a factor of $\frac{1-s}{1+r}$. Their objective function is therefore

$$
\max \alpha E\left\{\sum_{t=0}^{\infty}\left(\frac{1-s}{1+r}\right)^{t}(1-\tau) D_{t}\right\}
$$

Denoting $\beta=\frac{1-s}{1+r}$ we can see that this maximization problem is isomorphic to our main model in Eq. (3).

\section{References}

Alvarez, Luis H.R., Kanniainen, Vesa, Södersten, Jan, 1998. Tax policy uncertainty and corporate investment: a theory of tax-induced investment spurts. Journal of Public Economics 69 (1), 17-48.

Amromin, Gene, Harrison, Paul, Sharpe, Steven, 2007. How did the 2003 dividend tax cut affect stock prices? FRB Finance and Economics Discussion Series 2005-61. Asquith, Paul, Mullins, David, 1986. Equity issues and offering dilution. Journal of Financial Economics 15 (1/2), $61-89$.

Auerbach, Alan J., 1979. Wealth maximization and the cost of capital. Quarterly Journal of Economics 93 (3), 433-446.

Auerbach, Alan J., Hassett, Kevin A., 2006. Dividend taxes and firm valuation: new evidence. American Economic Review 96 (2), 119-123.

Auerbach, Alan J., Hassett, Kevin A., 2007. The 2003 dividend tax cuts and the value of the firm: an event study. In: Auerbach, A., Hines, J., Slemrod, J. (Eds.), Taxing Corporate Income in the 21st Century. Cambridge University Press, Cambridge, MA.

\footnotetext{
33 In a more realistic setting, a manager's probability to keep his job would increase the higher earnings he achieves, which could make him focus even more on short-term performance and could reinforce the myopia effect (Stein, 1988). Furthermore, a manager's future job opportunities could strongly depend on his observed short-run performance at the old firm, exacerbating the bias.
} 
Baker, George P., Jensen, Michael C., Murphy, Kevin J., 1988. Compensation and incentives: practice vs. theory. Journal of Finance 43 (3), $593-616$.

Bhattacharya, Sudipto, 1979. Imperfect information, dividend policy, and 'the bird in the hand' fallacy. Bell Journal of Economics 10 (1), $259-270$.

Black, Fischer, 1976. The dividend puzzle. Journal of Portfolio Management 2 (2), 5-8.

Blouin, Jennifer L., Raedy, Jana S., Shackelford, Douglas A., 2004. Did dividends increase immediately after the 2003 reduction in tax rates? NBER Working Paper w10301.

Brown, Jeffrey R., Liang, Nellie, Weisbenner, Scott, 2007. Executive financial incentives and payout policy: evidence from the 2003 dividend tax cut. Journal of Finance 62 (4), 1935-1965.

Chen, Hsuan-Chi, Ritter, Jay R., 2000. The seven percent solution. Journal of Finance 55 (2), 1105-1131.

Chetty, Raj, Saez, Emmanuel, 2005. Dividend taxes and corporate behavior: evidence from the 2003 dividend tax cut. Quarterly Journal of Economics 120 (3), $791-833$.

Chetty, Raj, Saez, Emmanuel, 2006. The effects of the 2003 dividend tax cut on corporate behavior: interpreting the evidence. American Economic Review Papers and Proceedings, vol. 96, pp. 124-129.

Chetty, Raj, Saez, Emmanuel, 2007. An agency theory of dividend taxation. NBER Working Paper, vol. w13538.

DeAngelo, Harry, DeAngelo, Linda, 1990. Dividend policy and financial distress: an empirical investigation of troubled NYSE firms. Journal of Finance 45 (5), 1415-1431.

Edlin, Aaron, Stiglitz, Joseph E., 1995. Discouraging rivals: managerial rent-seeking and economic inefficiencies. American Economic Review 85 (5), 1301-1312.

Gordon, Roger, Dietz, Martin, 2009. Dividends and taxes. In: Auerbach, Alan, Shaviro, Daniel (Eds.), Institutional Foundations of Public Finance: Economic and Legal Perspectives. Harvard University Press, Cambrdige, MA.

Gourio, François, Miao, Jianjun (2007), "Dynamic Effects of Permanent and Temporary Dividend Tax Policies on Corporate Investment and Financial Policies," Boston University, mimeo.

Greenwald, Bruce C., Stiglitz, Joseph E., Weiss, Andrew, 1984. Informational imperfections in the capital market and macroeconomic fluctuations. American Economic Review 74 (2), 194-199.

Greenwald, Bruce C., Stiglitz, Joseph E., 2003. Towards a New Paradigm in Monetary Economics. Cambridge University Press.

Grossman, Sanford J., Hart, Oliver D., 1980. Takeover bids, the free-rider problem, and the theory of the corporation. Bell Journal of Economics 11 (1), $42-64$.

Hall, Robert E., 1988. Commentary on "Financial Factors in Business Fluctuations," Proceedings. Federal Reserve Bank of Kansas City.

Jensen, Michael C., 1986. Agency costs of free cash flow, corporate finance, and takeovers. American Economic Review 76, 323-329.

King, Mervyn, 1977. Public Policy and the Corporation. Chapman and Hall, London.

Kocherlakota, Narayana R., 1996. The equity premium: it's still a puzzle. Journal of Economic Literature 34, 42-71.

Korinek, Anton and Stiglitz, Joseph E. (2008), "Political Economy in a Contestable Democracy" Columbia University, mimeo.

Mehra, Rajnish, Prescott, Edward C., 1985. The equity premium: a puzzle. Journal of Monetary Economics 15, 145-161.

Myers, Stewart C., Majluf, Nicholas S., 1984. Corporate financing and investment decisions when firms have information that investors do not have. Journal of Financial Economics 12, 187-221.

Poterba, James, Summers, Lawrence, 1985. The economic effects of dividend taxation. In: Altman, Edward, Subrahmanyam, Marti (Eds.), Recent Advances in Corporate Finance. Richard D. Irwin Publishers, Homewood, IL, pp. 227-284.

Ross, Stephen, 1977. The determination of financial structure: an incentive-signalling approach. Bell Journal of Economics 8 (1), 23-40.

Sinn, Hans-Werner, 1991. The vanishing Harberger triangle. Journal of Public Economics 45, 271-300.

Slemrod, Joel, 1988. Effect of taxation with international capital mobility. In: Aaron, Henry, Galper, Harvey, Pechman, Joseph A. (Eds.), Uneasy Compromise: Problems of a Hybrid Income-Consumption Tax. Brookings, Washington, DC, pp. 115-155.

Stein, Jeremy C., 1988. Takeover threats and managerial myopia. Journal of Political Economy 96 (1), 61-80.

Stiglitz, Joseph E., 1972. Some aspects of the pure theory of corporate finance: bankruptcies and take-overs. Bell Journal of Economics 3 (2), $458-482$.

Stiglitz, Joseph E., 1973. Taxation, corporate financial policy, and the cost of capital. Journal of Public Economics 2, 1-34.

Stiglitz, Joseph E., 1976. The corporation tax. Journal of Public Economics 5 (3-4), 303-311.

Stiglitz, Joseph E., Weiss, Andrew, 1981. Credit rationing in markets with imperfect information. American Economic Review 71, 393-410. 